Article

\title{
Entrepreneurship Education and Students' Entrepreneurial Intention in Higher Education
}

\author{
Hong Mei ${ }^{1}$, Ching-Hung Lee ${ }^{1, *(1)}$ and Yuanyuan Xiang ${ }^{2}$ \\ 1 School of Public Policy and Administration, Xi'an Jiaotong University, Xi'an 710049, China; \\ meihong@xjtu.edu.cn \\ 2 Savannah College of Art and Design, Atlanta, GA 30309, USA; jxiang@scad.edu \\ * Correspondence: leechinghung@xjtu.edu.cn; Tel.: +86-919-982-213
}

Received: 15 August 2020; Accepted: 8 September 2020; Published: 22 September 2020 updates

\begin{abstract}
Facing the challenging employment situation and the changing labor market, developing student entrepreneurial intention has attracted significant policy consideration in China. This study describes the background of entrepreneurship education in China's higher education institutes and explores the influences of entrepreneurship education on student entrepreneurial intention. Using data from a survey on students in China, this study finds that students in different types of institutions and different major fields had a different level of engagement in entrepreneurship education. Further, the higher the level of entrepreneurship education the students received, the stronger their self-efficacy of entrepreneurial decision-making was, and the stronger their entrepreneurial intention was. Student entrepreneurial decision-making self-efficacy played a mediating role between entrepreneurship education and student entrepreneurial intention. We found that entrepreneurship education has a positive effect on entrepreneurial intention. Entrepreneurship education course-taking has a positive effect on entrepreneurial decision-making. Furthermore, the positive effect of self-efficacy of entrepreneurial decision-making on entrepreneurial intention was also confirmed. We also found that self-efficacy of entrepreneurial decision-making played the significant role of mediator between entrepreneurship education and entrepreneurial intention. The findings also showed a difference between the current China context and the western context that taking entrepreneurship-related classes had more considerable influences on student entrepreneurial intention than entrepreneurship-related practicum. We discuss the implications of the improvement of higher education in China and relevance to other contexts.
\end{abstract}

Keywords: higher education; entrepreneurship education; entrepreneurial intention; self-efficacy of entrepreneurial decision-making

\section{Introduction}

Entrepreneurship is a topic of particular significance in a globalized and knowledge-based world economy [1]. Keener competition that spurs innovation and entrepreneurial drive has been encouraged during the wave of globalization. Under the unprecedented uncertainty, development of emerging technology and social change, entrepreneurship education plays a critical role in preparing citizens to face the impact of globalization and dramatic education and social transformation, especially in the developing China nowadays [2,3].

Since 1999, all colleges and universities in China started to adopt the "enrollment expansion policy," and the number of college graduates kept reaching new highs in recent years. The number of college graduates had increased from 2.12 million in 2003 to 7 million in 2013 (Ministry of Education of the People's Republic of China, 2013). It has had a growth rate as high as $230 \%$ in the past decade. At the same time, the traditional "two-way choice system" in the labor market (Ministry of Education of 
the People's Republic of China, 1997) has replaced the job assignment policy for college graduates that had been in place since the founding of the People's Republic of China. The two-way choice system is a system through which the college graduates can choose where to work, and the employers can choose whom to hire, has replaced the job assignment policy for college graduates that had been in place since the founding of the People's Republic of China. In this new policy environment, college graduates have more career choices, but they face competition in the labor market, and sometime they may become unemployed after graduation. In this new environment, their initial employment rate remained around 70 percent, which created high pressure for the whole society to find solutions to increase employment opportunities for college graduates (Figure 1).

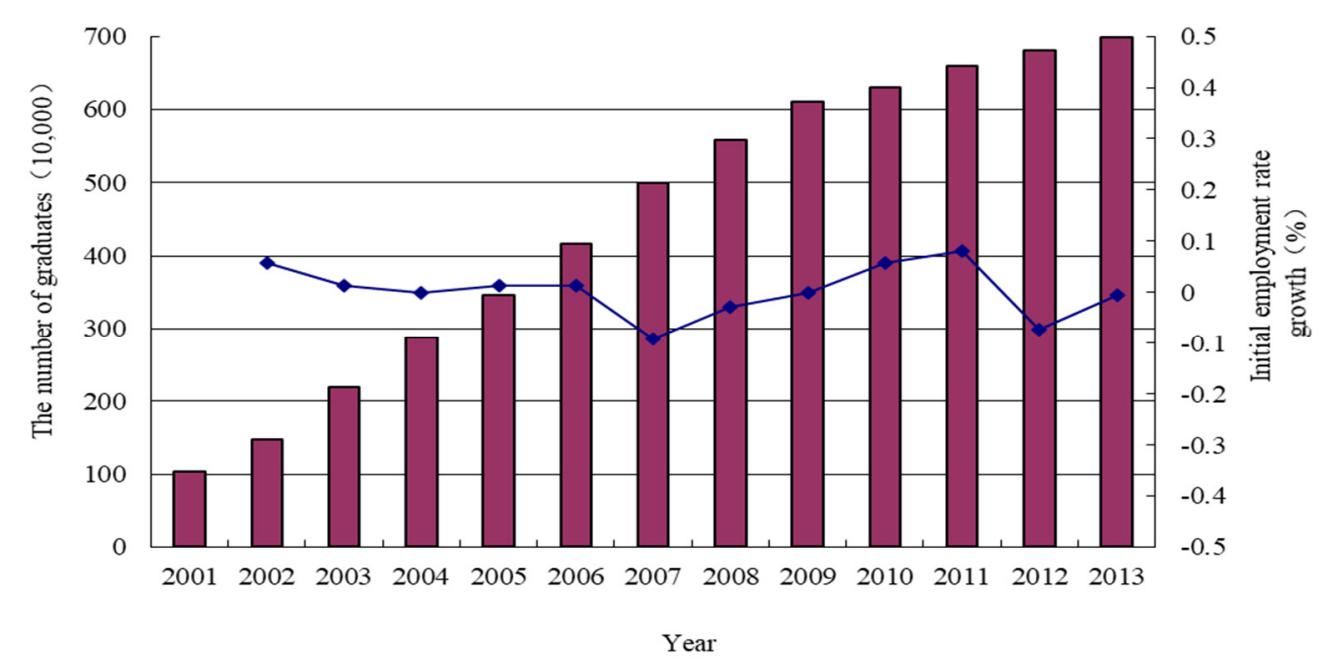

Figure 1. China's college graduates and the change of initial employment rate in 2001-2013.

In 2008, the State Council of the People's Republic of China issued the "Guiding Framework on Promoting Entrepreneurship-Driven Employment," pointing out the need to encourage college students "starting their own business," to resolve unemployment through setting up new enterprises and to promote the economic development of the country. In 2012, the Ministry of Education of the People's Republic of China announced new calls for colleges and universities to set up "entrepreneurship fundamental" courses for all students with entrepreneurship education included in the curriculum planning [4]. In this policy context, colleges and universities have been substantially modifying college curriculum and instruction to enhance entrepreneurship education as the driver and the incubator of innovation systems $[2,5,6]$. However, there is little effort to empirically study the educational reform in entrepreneurship education in the Chinese context. Thus, the importance of this research can bridge this gap and enrich the literature of the entrepreneurship education research in the eastern context. It is not clear, and exploration is needed to know the educational effects generated by different types of educational activities. For this reason, this paper attempts to focus on the entrepreneurship education and students' entrepreneurial intention in higher education to achieve three research objectives: (1) To understand the situation and effectiveness of the entrepreneurship courses; (2) To clarify the relationship between the implementation effects and different types of entrepreneurial education activities; (3) To clarify how entrepreneurial education activities affect students' entrepreneurial decision-making, self-efficacy and entrepreneurial intention.

The purpose of this study is to assess the outcomes of entrepreneurship education efforts in Chinese colleges and universities and to examine the relationship between the level of entrepreneurship education that college students have received and their entrepreneurial intention upon graduation. This article is composed as follows. The methods including data sources, variables and methods are discussed in Section 2. In Section 3, the conceptual research framework and hypotheses, with three major criteria: (1) entrepreneurship education, (2) self-efficacy in entrepreneurial decision-making and 
(3) entrepreneurial intention, is proposed, which is followed by analyzed results in Section 4. Section 5 concludes the article with a discussion of the results and the insights.

\section{Methods}

\subsection{Data Sources}

This study selected seven universities in Shaanxi Province as study sites. The selected seven universities in this study included four research universities and three other colleges and universities. The four research universities enjoy higher prestige and more reliable reputations than the other three colleges and universities. Meanwhile, the items in the questionnaires were adapted from some existing instruments. After pilot tests and some revisions of the instrument, the research team conducted the official distribution of questionnaires in 2013. The questionnaire used a 5-point Likert scale and contained the following parts: introduction, participant information, survey items on the levels of entrepreneurship education that the student received, student self-efficacy in five areas, and student entrepreneurial intention.

The adaption of the questionnaire explanations are as follows. 1. From November to December 2012 , the researcher issued a pre-test questionnaire to graduates of Xi'an Jiaotong University. A total of 90 pre-test questionnaires were distributed and 86 valid questionnaires were returned. According to the results of the pre-test questionnaire analysis, it is found that the reliability and validity of the three items in the Entrepreneurship Intention Survey Scale (IEIS) compiled by Thompson (2009) [7] are low, including "I am willing to save money for starting a company; I will not go to read books on how to start a company; I don't know how to start a business." 2. For the translation of foreign scale items, in the forecast survey, students reported that the expression of individual items is still not easy to understand, and does not conform to their way of thinking and expression; the researcher made a more conversational presentation of these topics.

Six hundred and eighty questionnaires were formed through two samplings. The first sampling is a random sampling based on the type of university. At present, Chinese universities can be divided into three major categories. The first category comprises the key universities of the 985 and 211 national projects. Such schools generally have a better quality of students, relatively sufficient education funds, and more active scientific research activities. Type 2 universities are ordinary colleges. Domestic colleges and universities account for the largest proportion and are generally supported by the province where they are located. Compared with high-ranking universities, the admission scores of such colleges are relatively lower, and the school funding is relatively low, mainly in the field of teaching; the third type of colleges are independent colleges and private colleges. China's independent colleges and private higher education have developed relatively late. Compared with the first two types of universities, their source of students and teaching and research levels are relatively weak. The researchers randomly selected three high-ranking institutions ( $\mathrm{Xi}^{\prime}$ an Jiaotong University, Chang'an University, Xidian University), two general institutions (Xi'an University of Architecture and Technology, Baoji University of Arts and Sciences), one independent college (Xi'an Jiaotong University City College) and one private college (Eurasia College) to conduct questionnaires. These seven colleges and universities can represent the distribution of colleges and universities in Shaanxi Province. The second sampling is a sample obtained by cluster sampling in these seven schools. The researchers use the class as a unit to randomly select classes of different majors to conduct a questionnaire survey. Before answering the questionnaire survey, subjects are informed of the purpose of the questionnaire and conduct surveys in strict accordance with academic ethics.

We received 643 responses out of 680 distributed survey questionnaires, representing a response rate of $93.2 \%$. Among them, there were 599 usable responses, representing $88.1 \%$ of the total responses (those questionnaires with insufficient collected information were removed). For the respondents whose survey questionnaires were used, $50.1 \%$ were male, and $49.9 \%$ were female students. In total, $77.5 \%$ of the respondents were from the northern region of China, while $22.5 \%$ were from the southern 
region. In addition, $56.6 \%$ of the respondents were from the research universities and $43.4 \%$ were from other colleges and universities. Furthermore, $36.6 \%$ of them were in the fields of Economics and Management, 55.3\% in the traditional Science, Technology, Engineering, and Mathematics (STEM) fields, and $8.1 \%$ from Humanities and Social Sciences.

\subsection{Variables}

Scholars have developed a series of scales for measuring "entrepreneurial self-efficacy". De Noble et al. (1999) [8] put forward several core entrepreneurial skills that are different from general management skills. They divide entrepreneurial self-efficacy into developing new products and market opportunities, solving unknown challenges, developing important human resources, defining core goals, building an innovation environment, and, initially based on six dimensions including investment relationship, a self-efficacy evaluation scale containing 35 items has been developed. The researchers Taylor and Betz (1983) [9] compiled the Career Decision Making Self-efficacy Scale (CDMSE), which contains five dimensions. Subsequently, the researchers continued to simplify and improve, reducing the number of items to 25 to form the CDMSE-FS (the Career Decision-Making Self-Efficacy Scale-Short Form) scale. table. This research is based on Taylor and Betz's expression of "entrepreneurial self-efficacy", which is modified into the questionnaire items used in this article. The questionnaire is listed in Table A1 Appendix A. Meanwhile, Table A2 Appendix A shows the degree of participation of college students in entrepreneurship education.

Independent variable: According to our research, entrepreneurship education, the independent variable, was to understand how much entrepreneurship education students had during college, which was divided into participating in entrepreneurship-related activities (practicum hereafter) and taking an entrepreneurship-related course (course taking hereafter). The measuring questions were designed according to the current implementation of entrepreneurship education in Chinese universities. The survey on Entrepreneurship practice education includes two parts: 1 . The overall situation of participation in practical education. 2. What types of start-up practice activities have you participated in? For 8 types of start-up practice activities, please answer "YES" or "NO". The survey on start-up curriculum education also includes two parts: 1 . The overall situation of participation in curriculum education. 2. What types of Entrepreneurship education activities have you participated in? For 8 types of Entrepreneurship education curriculums, please answer "YES" or "NO." Cronbach's alpha values are the results of scores on the 5-point scale. For entrepreneurship practicum and course taking, the reliability measure as reflected by Cronbach's $\alpha$ was 0.738 and 0.813 . Dependent variables: Entrepreneurial intention, as the dependent variable, was students' attitude towards whether they are willing to be engaged in entrepreneurship in the future. Mainly based on the Individual Entrepreneurial Intent Scale (IEIS) designed by Thompson (2009) [7], the items were modified with a deletion of poor-validity questions according to the pilot-study results. The reliability measure, as reflected by Cronbach's $\alpha$, was 0.728 .

Mediating variables: Self-efficacy of entrepreneurial decision-making, as the mediating variable, was used to measure students' future self-confidence of entrepreneurship. The measuring questions were mainly drawn on the Career Decision Making Self-efficacy Scale (CDMSE) designed by Peng and Long (2001) [10] as well as Taylor and Betz (1983) [9]. There were five dimensions and 26 individual items to measure student self-efficacy of entrepreneurial decision-making. The reliability measure for goal setting, self-appraisal, information acquisition, plan making, problem-solving is between 0.793 to 0.858 .

Control variables: In addition to the above variables, because of differences in gender roles and social divisions of labor in China, males and females could have different attitudes towards entrepreneurship. Thus, we included a variable regarding student gender in the study (Male $=1$ and female $=0$ ). Moreover, there are differences across the North and the South of China in terms of economic foundations, economic environments and social points of view, which may also affect the students' attitudes towards entrepreneurship (South $=1$ and north $=0$ ). In addition, students in 
different major fields and institutions may have different experiences and perspectives. Therefore, we included students' major fields (students in the STEM fields as the reference group) and attended institutions (students in research universities as the reference group) together with gender and regional differences as control variables. Besides, students in a different stage of their educational careers were considered and controlled for in the data analysis (seniors in college as the reference group). All description of variables is listed in Table 1.

Table 1. Description of Variables.

\begin{tabular}{|c|c|c|}
\hline Measure & Description & Cronbach's $\alpha$ \\
\hline Male & A dummy variable $($ Yes $=1$, No $=0)$ & \\
\hline Origin of Residency & A dummy variable $($ South $=1$, North $=0$ ) & \\
\hline Research University & A dummy variable, $($ Yes $=1, \mathrm{No}=0)$ & \\
\hline Economics and Management & A dummy variable $($ Yes $=1$, No $=0)$ & \\
\hline $\begin{array}{l}\text { Humanities and Social } \\
\text { Sciences }\end{array}$ & A dummy variable $($ Yes $=1$, No $=0)$ & \\
\hline STEM major & Reference group & \\
\hline Graduate Student & A dummy variable $($ Yes $=1$, No $=0)$ & \\
\hline Other Undergraduates & A dummy variable $($ Yes $=1$, No $=0)$ & \\
\hline Seniors in College & Reference group & \\
\hline \multirow[b]{2}{*}{ Practicum } & $\begin{array}{l}\text { A. Choose from } 1 \text { to } 5 \text { for the following }(1=\text { Never } \\
\text { participated, } 5=\text { Often participated: } \\
\text { The situation of your participation in practices } \\
\text { related to start-up during your school }\end{array}$ & 0.738 \\
\hline & $\begin{array}{l}\text { B. Whether they have participated in the following } \\
\text { activities (Yes }=1, \text { No }=0 \text { ): } \\
\text { (a) Lectures by successful entrepreneurs or experts. } \\
\text { (b) Consulting in entrepreneurship consulting } \\
\text { institutions established by schools. } \\
\text { (c) Visiting student entrepreneurial practice bases } \\
\text { established by schools and enterprises. } \\
\text { (d) Social research in entrepreneurship. } \\
\text { (e) Student entrepreneurial clubs. } \\
\text { (f) Training before entrepreneurship competitions. } \\
\text { (g) Entrepreneurship competitions. } \\
\text { (h) Applying for college student entrepreneurship } \\
\text { funds. }\end{array}$ & \\
\hline & $\begin{array}{l}\text { A. Choose from } 1 \text { to } 5 \text { for the following ( } 1=\text { Never } \\
\text { learned, } 5 \text { = More learned: } \\
\text { The situation of your participation in learning } \\
\text { curriculum related to start-up during your school }\end{array}$ & 0.813 \\
\hline Courses-Taking & $\begin{array}{l}\text { B. Whether they have taken the following courses } \\
\text { related to (Yes = 1, No =0): } \\
\text { (a) Career development. } \\
\text { (b) Entrepreneurial guidance. } \\
\text { (c) Entrepreneurship foundations. } \\
\text { (d) Entrepreneurial opportunity recognition. } \\
\text { (e) Writing business plans. } \\
\text { (f) Venture finances. } \\
\text { (g) Entrepreneurship policies and regulations. } \\
\text { (h) Entrepreneurial business management. }\end{array}$ & \\
\hline
\end{tabular}


Table 1. Cont.

\begin{tabular}{|c|c|c|}
\hline Measure & Description & Cronbach's $\alpha$ \\
\hline Entrepreneurial Intention & $\begin{array}{l}\text { Choose from } 1 \text { to } 5 \text { for the following }(1=\text { strongly } \\
\text { disagree, } 5=\text { strongly agree): } \\
\text { I intend to ..... } \\
\text { (a) be employed first after graduation and then start } \\
\text { my own business several years later, } \\
\text { (b) look for entrepreneurial opportunities in my daily } \\
\text { life, } \\
\text { (c) spend time learning about entrepreneurship. }\end{array}$ & 0.728 \\
\hline Goal-Setting & $\begin{array}{l}\text { Choose from } 1 \text { to } 5 \text { for the following }(1=\text { no } \\
\text { confidence at all, } 5=\text { full confidence): } \\
\text { I believe that ...... } \\
\text { (a) entrepreneurship is my ideal career choice, } \\
\text { (b) entrepreneurship is valuable to me, } \\
\text { (c) entrepreneurship is in line with my hobbies. }\end{array}$ & 0.809 \\
\hline
\end{tabular}

Choose from 1 to 5 for the following $(1=$ not agree at all, 5 = fully agree):

I am able to ......, or I believe that ......

(a) negotiate with others to get entrepreneurial support,

Self-Appraisal (b) I have some entrepreneurial capabilities,

(c) explore business opportunities in my daily life,

(d) influence the people around me to support or participate in my business plan,

(e) create learning and working atmospheres that encourage innovation,

(f) build business teams by using my own teamwork.

Choose from 1 to 5 for the following $(1=$ not agree at all, 5 = fully agree):

I am able to ......, or I believe that ......

(a) know the basic situation of current and prospect entrepreneurship,

InformationAcquisition

(b) know specific affairs that are required by entrepreneurship,

(c) know current and prospect entrepreneurship in my majored field,

(d) entrepreneurship can bring good economic benefits,

(e) learn educational and training information related to entrepreneurship.

Choose from 1 to 5 for the following ( $1=$ not agree at all, 5 = fully agree):

I am able to ......, or I know ......

(a) make plans to achieve the entrepreneurial goals,

(b) make specific action plans for the completion of the entrepreneurial plans,

Plan-Making (c) accumulate working and practicing experience of entrepreneurship,

(d) participate in learning and training for future entrepreneurship,

(e) my career plans for the coming 5-10 years,

(f) I am able to acquire more entrepreneurial knowledge and skills. 
Table 1. Cont.

\begin{tabular}{|c|c|c|}
\hline Measure & Description & Cronbach's $\alpha$ \\
\hline Problem-Solving & $\begin{array}{l}\text { Choose from } 1 \text { to } 5 \text { for the following ( } 1 \text { = not agree at } \\
\text { all, } 5 \text { = fully agree): } \\
\text { I am able to ... . . , or I will ... ... } \\
\text { even when I am frustrated, } \\
\text { (a) continue working for my entrepreneurial goals, } \\
\text { (b) solve financial problems in entrepreneurship } \\
\text { through different ways, } \\
\text { (c) choose entrepreneurship even with parents' } \\
\text { objections, } \\
\text { (d) use national policies and regulations to protect } \\
\text { my entrepreneurial rights from infringement, } \\
\text { (e) choose entrepreneurship even if the social } \\
\text { situation of economic development is not optimistic, } \\
\text { (f) study and work hard to prepare for the future } \\
\text { entrepreneurship even if I am facing failure or } \\
\text { negative feedback. }\end{array}$ & 0.799 \\
\hline
\end{tabular}

\subsection{Methods of Analysis}

After conducting a bivariate correlation analysis for the variables used in this study, we used multiple regressions to examine the relationship between student entrepreneurship education and their self-efficacy in entrepreneurial decision-making. Next, we used multiple regressions to examine the relationship between student self-efficacy and student entrepreneurial intention. Finally, the relationship between entrepreneurship education and the entrepreneurial intention was examined by multiple regressions, where student self-efficacy in entrepreneurial decision-making was included in a subsequent block. Results from these steps could help explain whether student self-efficacy in entrepreneurial decision-making played a role as a mediating variable. The bivariate correlation coefficients among variables were all below the conventional 0.7 threshold (Table 2), and the tolerance statistics for all independent variables were above 0.5 and the variance inflation factors were all below 2.0, suggesting multi-collinearity was not an issue in this study.

Table 2. Correlation matrix of variables.

\begin{tabular}{ccccccccc}
\hline & $\mathbf{1}$ & $\mathbf{2}$ & $\mathbf{3}$ & $\mathbf{4}$ & $\mathbf{5}$ & $\mathbf{6}$ & $\mathbf{7}$ & $\mathbf{8}$ \\
\hline 1. Practicum & 1.000 & & & & & & & \\
2. Course-Taking & $0.359 *$ & 1.000 & & & & & & \\
3. Entrepreneurial Intention & $0.240^{*}$ & $0.403 *$ & 1.000 & & & & & \\
4. Goal-Setting & $0.194^{*}$ & $0.239 *$ & $0.537^{*}$ & 1.000 & & & & \\
5. Self-appraisal & $0.168^{*}$ & $0.252^{*}$ & $0.480 *$ & $0.587^{*}$ & 1.000 & & & \\
6. Information Acquisition & $0.203^{*}$ & $0.312^{*}$ & $0.381^{*}$ & $0.479 *$ & $0.623 *$ & 1.000 & & \\
7. Plan-Making & $0.162 *$ & $0.306^{*}$ & $0.471^{*}$ & $0.547^{*}$ & $0.675^{*}$ & $0.691 *$ & 1.000 & \\
8. Problem-Solving & $0.128^{*}$ & $0.284^{*}$ & $0.462 *$ & $0.534^{*}$ & $0.605 *$ & $0.555^{*}$ & $0.679 *$ & 1.000 \\
\hline
\end{tabular}

Notes: $\mathrm{N}=599, * p<0.01$ (two-tailed).

\section{Theory}

\subsection{Entrepreneurship Education}

"Entrepreneurship education" refers to a range of educational courses and activities aiming at improving entrepreneurial attitudes and skills. In 1979, David Birch, a researcher at Massachusetts Institute of Technology, published a research report titled The Job Generation Process, which revealed the importance of entrepreneurship in providing new employment opportunities and promoting economic development. This report has started a heated discussion on entrepreneurship education in 
the society as well as in the higher education sector, and further pushed forward entrepreneurship education in colleges and universities.

Debates on whether entrepreneurship can be taught have been abundant [11-13]. Some researchers affirmed the value of entrepreneurship education [14,15]. They argued that the emergence of entrepreneurship education helped build linkages between the individual and the society and the economy, and helped connect higher education and the economy [16-19]. Students participating in entrepreneurship education show an increasing prevalence in attitudes and perceived behavioral control to reduce start-up risks [20].

Vocational education and training, as well as general education, play crucial roles in preparing young people for the labor market, vocational education and training are core factors in smoothing the transition from school to work [21]. Pardo-García and Barac (2020) [22] found that an innovative training itinerary is an opportunity to develop students' creativity and entrepreneurship to create something from zero, being proactive, and solving a need that exists in the society. The methodologies used to measure the efficiency of entrepreneurial education programs are mainly focused on three areas: entrepreneurial intention, entrepreneurial activity, and acquired skills [23]. Empirical studies have found that there is a significant relationship between students' behavior and students' access to entrepreneurship education. Those students who have received entrepreneurship education are better at taking risks $[11,12,24]$.

Nabi (2018) [25] conducted a longitudinal survey of business students at a British university and found higher entrepreneurial learning and inspiration, compared to their non-EE counterparts. They found that entrepreneurship education had greatly improved college students' business knowledge and skills, and significantly increased their engagement in small businesses after graduation [26-29]. Laguna-Sánchez et al. (2020) [23] found that the students attained two types of skills, acquiring a higher level of proficiency in entrepreneurial skills, as well as transversal competencies through training programs. Some other studies also indicate strong correlations between student participation in entrepreneurship education and the formation of their entrepreneurial intention [6,30-32]. Participants of entrepreneurship education programs are more likely to have higher intention to form their own businesses compared to non-participants [33,34].

Zaring et al. (2018) [35] performed a cluster analysis of all 37 universities with entrepreneurship educations in one country. They called for long term longitudinal research to uncover the effects of entrepreneurial education: it should not be expected that entrepreneurship education will have immediate results in the form of direct venture employment and growth, irrespective of its orientation. However, indirectly and over time, it is a precondition for sustainable growth.

\subsection{Entrepreneurship Intention}

"Intention" is considered as the best predictor of planned behavior [36]. The Theory of Planned Behavior (TPB) suggests that attitude can predict intention, and the intention further leads to planned behavior. This theory has provided vital support to explain the relationship between attitude, intention and planned behavior. Accordingly, the TPB model has become one of the major theoretical models adopted in the research field of entrepreneurial intention [37]. "Entrepreneurial intention" is an individual's subjective attitude towards a willingness to start one's own business, which includes the "willingness to venture" mental state and behavioral tendencies. Through empirical research, Kolvereid (1996) [36] analyzed indirect influence on the entrepreneurial intention from the family background, gender and previous entrepreneurial experience. Other researchers have validated and improved the TPB model in entrepreneurial studies [30,36,38], and confirmed that the formation of entrepreneurial behavior depends primarily on the formation of entrepreneurial intention [39]. Cano and Tabares (2017) [40] determined the factors of entrepreneurial intention in Colombia university students by a GUESSS (the Global University Entrepreneurial Spirit Students' Survey) study and found personal motivations of being an entrepreneur, the strength of entrepreneurial intention, as well as the influence of family. Meanwhile, the social context of university students was also identified to 
influence entrepreneurial intention in Colombia. Faloye (2018) [41] found entrepreneurship education, ability to take risks, family and friends including mentor were the significant effects of entrepreneurship intentions among the study participants. The more grounded an individual's entrepreneurial intention the more probable it is for him/her to engage in entrepreneurial behaviour [42]. To improve the individual's entrepreneurship intention, entrepreneurship educators may need to provide various learning opportunities for students [43].

\subsection{Self-Efficacy of Entrepreneurial Decision-Making}

"Self-efficacy" is a general concept of self-appraisal, which has to be put into a particular context to explain its meaning [44-46]. Self-efficacy of entrepreneurial decision-making is an individual's subjective perception and confidence in deciding to start a career in the process of career selection. It is a derivative of self-efficacy in the aspect of entrepreneurial decision-making. In individuals' entrepreneurial decision-making, if they can predict better development through entrepreneurship, they will be more likely to choose entrepreneurship; otherwise, they will avoid it. The Self-Efficacy Theory proposed by Bandura is based on social learning theories to explain individuals' actions in particular contexts. This theory suggests that whether an individual takes action depends on one's confidence in completing a particular task [46,47].

Researchers suggest that low self-efficacy of entrepreneurial decision-making will hinder their career exploration and the development of career decision-making skills [9,46]. Based on Bandura's theory, Lent and Brown (2005) [45] proposed the Social Cognitive Career Theory (SCCT), which has integrated psychological development with social, economic and other factors. Guided by the SCCT model, researchers found that self-efficacy of entrepreneurial decision-making can predict the formation of entrepreneurial intention; both entrepreneurial self-efficacy and entrepreneurial intention can influence individuals' entrepreneurial choices [48]. By comparing different countries, a study has also verified that college students' self-efficacy of entrepreneurial decision-making has influences on their entrepreneurial intention [49]. Researchers have found that encouragement from educational institutions, particularly universities, encourages individual self-efficacy and strengthens intention towards entrepreneurship. Entrepreneurship education impacts on students' entrepreneurial attitude and self-efficacy, which increases the likelihood of entrepreneurial intentions among students. Researchers [50,51] have found Curricular and extracurricular programs for entrepreneurship based on self-efficacy had significant effects on innovative start-up intentions.

Another empirical study [52] has found entrepreneurial self-efficacy plays an intermediary role in entrepreneurial antecedents, risk-taking tendencies and entrepreneurial intention. In the research of Oyugi (2015) [53], self-efficacy was found to partially mediate the entrepreneurship education and entrepreneurial intention.

With the development of the practice and research of entrepreneurship education, more researchers have turned their attention to analyzing how student psychological factors influence students' entrepreneurial choices. For example, after the "action-oriented" entrepreneurship education, students have a higher evaluation of their self-efficiency in entrepreneurship [54], and entrepreneurship training affects entrepreneurial knowledge acquisition and self-efficacy.

\subsection{Conceptual Research Framework and Hypotheses}

The Theory of Planned Behavior (TPB) proposed by Ajzen (1991) was applied to justify the choice of the dependent variables in the entrepreneurial intention of the study. Following the traditional frameworks in studying college impact on students, Astin's (1993) Input-Environment-Outcome (I-E-O) model and Pascarella's (1985) causal model were used to specify the interrelations among the variables in the study. Individually, the relationship between entrepreneurship education and students' entrepreneurial intention was examined, after controlling for inputs such as student backgrounds. Entrepreneurship education is divided into two categories-entrepreneurship course taking and entrepreneurship practicum. 
Furthermore, our study has benefited from related theories on self-efficacy [47]. Self-efficacy of entrepreneurial decision-making is used as a mediator. This study will apply the measurement of self-efficacy of entrepreneurial decision-making designed by Taylor and Betz (1983) [9] to analyze college students' multidimensional confidence in entrepreneurial decision-making, including self-appraisal, information acquisition, goal setting, plan-making and problem-solving. To summarize, the theoretical framework of this study and the relationship between the variables are presented in Figure 2 below.

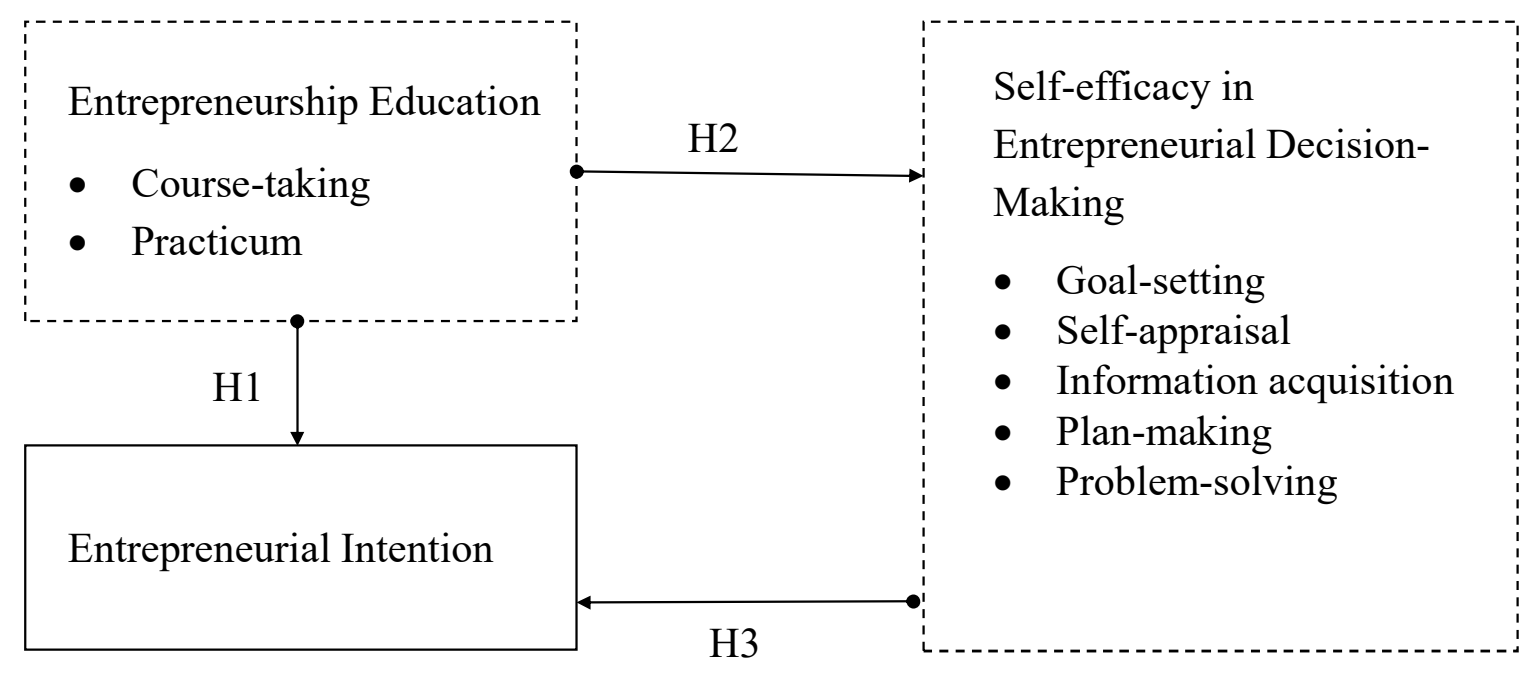

Figure 2. Conceptual research framework.

Based on the literature review, we developed the following three hypotheses to guide our study:

Hypothesis 1. The more entrepreneurship education the students receive, the stronger their entrepreneurial intention is.

Hypothesis 2. The more entrepreneurship education the students receive, the higher their self-efficacy of entrepreneurial decision-making is.

Hypothesis 3. The higher self-efficacy of entrepreneurial decision-making the students have, the stronger their entrepreneurial intention is. Self-efficacy of entrepreneurial decision-making play the role of mediator between entrepreneurship education and entrepreneurial intention.

\section{Results}

Results of descriptive statistical analysis (as shown in Table 1) show that the mean score for entrepreneurship practicum was 0.196 . The sample mean score for course-taking was 0.245 . The scores here are for the eight types of curriculum education. Students gave a score from 1 to 5 points. The 1-5, respectively, represents "never learned" to "systematic learning." For the eight types of practical education activities, 1-5 scores, respectively, represent "never participated" to "frequently participated." Both the above scores are low, which indicates that in the systematic entrepreneurial education system, students usually only follow the minimum requirements and "get a little taste" in entrepreneurial education activities. This is basically in line with the real situation we understand.

The mean score of entrepreneurial intention was 3.458. Besides, the mean scores of goal setting, self-appraisal, information acquisition, plan-making, problem-solving were between 2.947 and 3.147. When the measure of student practicum was used as a dependent variable (the first column in Table 3), students' background characteristics, attended institutions, and major fields had little relation with participation in practicum activities as entrepreneurship education. Entrepreneurship education is with the exception that students at other colleges and universities have a higher level of practicum than 
those in research universities. There were some significant relationships between attended institutions, major fields and students taking classes as the format of entrepreneurship education (the second column in Table 3). In particular, students in the fields of economics and management, humanities and social sciences were more likely to take entrepreneurship-related courses than students in the STEM fields. Students in other colleges and universities had a higher level of entrepreneurship-related course taking activities than those at research universities.

The remaining columns in Table 3 reported the results from regression analyses when the sub-scales of self-efficacy in entrepreneurial decision-making were the dependent variables. Comparing results from model 1 and model 2, with or without entrepreneurship education, made a significant difference on the five sub-scales in student self-efficacy in entrepreneurial decision-making, suggesting that entrepreneurship education had a significant impact on entrepreneurial decision-making self-efficacy. The variances explained by the two types of entrepreneurship education ranged from $6.9 \%$ (self-appraisal) to $9.4 \%$ (information acquisition and plan-making). Course taking had significant and positive relations with all five sub-scales in self-efficacy in entrepreneurial decision-making, indicating that course taking in the domain of entrepreneurship education could boost student self-efficacy broadly. Participation in practicum was significantly and positively related to "goal setting," "self-appraisal," and "information acquisition" but not for the other two sub-scales.

Table 4 reported the results when student entrepreneurial intention was the dependent variable. In the first model, there were some significant relationships between student gender, type of university, the origin of residency and entrepreneurial intentions (the second column in Table 4). The variables used explained $2.2 \%$ of the variance in entrepreneurial intention. In model 2, with two types of entrepreneurship education included, $18.8 \%$ of the variance in entrepreneurial intention was explained. Thus, entrepreneurship education measures helped explain $16.6 \%$ of the total variance of student entrepreneurial intention. Both types of entrepreneurship education were significantly and positively related to student entrepreneurial intention. Thus, the more entrepreneurship education college students had, the stronger their entrepreneurial intention was. H1 was supported based on this result. Regarding the two types of entrepreneurship education, the coefficient of the participation in practicum was much smaller than that of course taking. Since the measures on the two types of entrepreneurship education were normalized similarly, this indicates that taking the class had a relatively more considerable influence on entrepreneurial intention than the participation in practicum activities in this study context. 
Table 3. Entrepreneurship education and entrepreneurial decision-making self-efficacy.

\begin{tabular}{|c|c|c|c|c|c|c|c|c|c|c|c|c|}
\hline \multirow{2}{*}{ Variables } & \multirow{2}{*}{ Practicum } & \multirow{2}{*}{ Course-Taking } & \multicolumn{2}{|c|}{ Goal-Setting } & \multicolumn{2}{|c|}{ Self-Appraisal } & \multicolumn{2}{|c|}{$\begin{array}{l}\text { Information } \\
\text { Acquisition }\end{array}$} & \multicolumn{2}{|c|}{ Plan-Making } & \multicolumn{2}{|c|}{ Problem-Solving } \\
\hline & & & Model 1 & Model 2 & Model 1 & Model 2 & Model 1 & Model 2 & Model 1 & Model 2 & Model 1 & Model 2 \\
\hline \multirow{2}{*}{ Male } & -0.002 & $0.036^{*}$ & 0.139 & 0.105 & 0.156 & $0.123 *$ & $0.148 *$ & 0.110 & 0.071 & 0.025 & 0.023 & -0.021 \\
\hline & $(0.012)$ & $(0.015)$ & $(0.079)$ & $(0.077)$ & $(0.065)$ & $(0.063)$ & $(0.062)$ & $(0.060)$ & $(0.069)$ & $(0.066)$ & $(0.066)$ & $(0.063)$ \\
\hline \multirow{2}{*}{ South } & -0.001 & 0.016 & 0.153 & 0.138 & -0.016 & -0.031 & 0.020 & 0.003 & 0.057 & 0.036 & 0.032 & 0.012 \\
\hline & $(0.013)$ & $(0.018)$ & $(0.092)$ & $(0.089)$ & $(0.075)$ & $(0.073)$ & $(0.073)$ & $(0.069)$ & $(0.081)$ & $(0.077)$ & $(0.076)$ & $(0.073)$ \\
\hline \multirow{2}{*}{ Graduate } & 0.033 * & 0.031 & 0.013 & -0.048 & 0.000 & -0.047 & 0.172 * & 0.120 & 0.092 & 0.038 & -0.078 & -0.122 \\
\hline & $(0.014)$ & $(0.019)$ & $(0.099)$ & $(0.096)$ & $(0.081)$ & $(0.078)$ & $(0.078)$ & $(0.074)$ & $(0.087)$ & $(0.083)$ & $(0.082)$ & $(0.079)$ \\
\hline Other & 0.008 & 0.003 & 0.005 & -0.006 & 0.058 & 0.051 & 0.055 & 0.047 & -0.033 & -0.040 & -0.064 & -0.069 \\
\hline Undergraduates & $(0.016)$ & $(0.021)$ & $(0.112)$ & $(0.108)$ & $(0.091)$ & $(0.088)$ & $(0.088)$ & $(0.084)$ & $(0.098)$ & $(0.093)$ & $(0.092)$ & $(0.088)$ \\
\hline Economics and & 0.020 & $0.077^{* * *}$ & 0.042 & -0.053 & 0.046 & -0.036 & 0.122 & 0.028 & 0.027 & -0.080 & -0.090 & $-0.188^{* *}$ \\
\hline Management & $(0.012)$ & $(0.016)$ & $(0.083)$ & $(0.082)$ & $(0.068)$ & $(0.067)$ & $(0.066)$ & $(0.064)$ & $(0.073)$ & $(0.071)$ & $(0.069)$ & $(0.067)$ \\
\hline Humanities and & 0.038 & $0.078^{*}$ & -0.150 & -0.261 & -0.114 & -0.206 & -0.052 & -0.157 & $-0.146^{*}$ & -0.262 & -0.139 & -0.241 \\
\hline Social Sciences & $(0.024)$ & $(0.031)$ & $(0.163)$ & $(0.158)$ & $(0.133)$ & $(0.129)$ & $(0.128)$ & $(0.123)$ & $(0.143)$ & $(0.137)$ & $(0.135)$ & $(0.130)$ \\
\hline Other Colleges & $0.026^{*}$ & $0.041^{*}$ & 0.094 & 0.030 & 0.060 & 0.008 & $0.157^{*}$ & 0.098 & 0.125 & 0.062 & 0.140 * & 0.085 \\
\hline and Universities & $(0.012)$ & $(0.016)$ & $(0.084)$ & $(0.082)$ & $(0.069)$ & $(0.067)$ & $(0.066)$ & $(0.064)$ & $(0.074)$ & $(0.071)$ & $(0.070)$ & $(0.067)$ \\
\hline \multirow{2}{*}{ Practicum } & & & & $0.893^{* *}$ & & 0.541 * & & $0.562 *$ & & 0.371 & & 0.187 \\
\hline & & & & $(0.289)$ & & $(0.236)$ & & $(0.224)$ & & $(0.250)$ & & $(0.237)$ \\
\hline \multirow{2}{*}{ Course Taking } & & & & $0.998^{* * *}$ & & $0.924^{* * *}$ & & $1.070^{* * *}$ & & $1.308^{* * *}$ & & $1.230^{* * *}$ \\
\hline & & & & $(0.222)$ & & $(0.181)$ & & $(0.172)$ & & $(0.192)$ & & $(0.182)$ \\
\hline $\mathrm{R}^{2}$ & 0.022 & 0.061 & 0.013 & 0.083 & 0.016 & 0.085 & 0.029 & 0.123 & 0.011 & 0.107 & 0.013 & 0.099 \\
\hline$\Delta \mathrm{R}^{2}$ & & & & 0.070 & & 0.069 & & 0.094 & & 0.094 & & 0.086 \\
\hline $\mathrm{F}$ & 1.860 & $5.455^{* * *}$ & 1.127 & $5.900^{* * *}$ & 1.333 & $6.088^{* * *}$ & $2.521 *$ & $9.184^{* * *}$ & 0.902 & $7.808^{* * *}$ & 1.084 & $7.227^{* * *}$ \\
\hline
\end{tabular}


Table 4. Entrepreneurship education, self-efficacy, and entrepreneurial intention.

\begin{tabular}{cccc}
\hline Variables & \multicolumn{3}{c}{ Entrepreneurial Intention } \\
\cline { 2 - 4 } & Model 1 & Model 2 & Model 3 \\
Male & $0.142^{*}(0.070)$ & $0.083(0.064)$ & $0.044(0.055)$ \\
South & $0.168^{*}(0.081)$ & $0.141(0.074)$ & $0.105(0.063)$ \\
Graduate & $0.112(0.087)$ & $0.037(0.080)$ & $0.078(0.068)$ \\
Other Undergraduates & $0.017(0.098)$ & $0.007(0.090)$ & $0.016(0.076)$ \\
Economics and Management & $0.016(0.073)$ & $-0.125(0.068)$ & $-0.073(0.059)$ \\
Humanities and Social Sciences & $0.062(0.143)$ & $-0.092(0.132)$ & $0.052(0.112)$ \\
Other Colleges and Universities & $0.149 *(0.074)$ & $0.064(0.068)$ & $0.046(0.058)$ \\
Practicum & & $0.655 *(0.241)$ & $0.317(0.207)$ \\
Course-Taking & & $1.670 * *(0.185)$ & $1.070 * * *(0.164)$ \\
Goal-Setting & & & $0.267 * * *(0.037)$ \\
Self-appraisal & & & $0.160 * *(0.052)$ \\
Information Acquisition & & & $-0.080(0.052)$ \\
Plan-Making & & & $0.098(0.054)$ \\
Problem-Solving & & & $0.116^{*}(0.050)$ \\
$\mathrm{R}^{2}$ & & 0.188 & 0.421 \\
$\Delta \mathrm{R}^{2}$ & & 0.166 & 0.233 \\
$\mathrm{~F}$ & 1.913 & $15.199 * * *$ & $30.301 * *$ \\
\hline
\end{tabular}

Notes: $\mathrm{N}=599,{ }^{* * *} p<0.001,{ }^{* *} p<0.01,{ }^{*} p<0.05$.

In model 3 in Table 4, individual characteristics, entrepreneurship education, and entrepreneurial decision-making self-efficacy explained $42.1 \%$ of the variance in entrepreneurial intention. Compared with model 2, the five sub-scales of entrepreneurial decision-making self-efficacy explained $23.3 \%$ of the variance, indicating that entrepreneurial decision-making self-efficacy had a significant influence on entrepreneurial intention. This implied that $\mathrm{H} 2$ was supported. Specifically, "goal-setting," "self-appraisal," and "problem-solving" were significantly and positively related to student entrepreneurial intention. At the same time, the other two sub-scales (information acquisition and plan-making) were not statistically significant. When the five sub-scales were included, the significance of "practicum" disappeared and the magnitude of the coefficient for "course taking" was reduced by $1 / 3$, suggesting that entrepreneurial decision-making self-efficacy played a mediating role between entrepreneurship education and entrepreneurial intention. The results also showed that $\mathrm{H} 3$ was verified.

Entrepreneurship Education has a significant and positive influence on the different dimensions of self-efficacy of entrepreneurial decision-making, as shown in Table 3. Meanwhile, from the information in Table 3 and model 3 of Table 4, the more independent variables of self-efficacy of entrepreneurial decision-making are added into regression analysis, the weaker their entrepreneurial intention is. However, the explanation strength of the regression model is enhanced. It indicates that self-efficacy of entrepreneurial decision-making plays the role of mediator between entrepreneurship education and entrepreneurial intention. The results also indicated that $\mathrm{H} 3$ was supported.

\section{Discussion and Conclusions}

Results from this study support the effect of entrepreneurship education in the context of Chinese higher education. First, the more entrepreneurship education college students have in colleges and universities, the stronger their entrepreneurial intention is (H1 could be supported). Entrepreneurship education in the format of course-taking appears to have more considerable influence on student entrepreneurial intention than participation in practicum. Second, the more entrepreneurship education college students have received in school, the higher self-efficacy of entrepreneurial decision-making the students have ( $\mathrm{H} 2$ could be supported). Entrepreneurship-related course taking has a broader positive influence on student self-efficacy than participation in practicum. Third, student self-efficacy sub-scales such as goal setting, self-appraisal, and problem-solving are significantly and positively related to 
entrepreneurial intention. Student self-efficacy in entrepreneurial decision-making plays a mediating role between entrepreneurship education and entrepreneurial intention ( $\mathrm{H} 3$ could be supported).

There is little effort to empirically study the educational reform in entrepreneurship education in Chinese. Thus, this research bridges this gap and enriches the literature of the entrepreneurship education research in the eastern context. It can enrich literature of entrepreneurship education in three aspects: (1) the situation and effectiveness of the entrepreneurship courses; (2) the relationship between the implementation effects and different types of entrepreneurial education activities; (3) how entrepreneurial education activities affect students' entrepreneurial decision-making, self-efficacy and entrepreneurial intention.

Many other findings are worth mentioning. Students in economics and management and humanities and social sciences tend to take more courses related to entrepreneurship education than those in the STEM fields in Chinese colleges and universities. It may not be so surprising about students in economics and management because of the relevance of those major fields to the business world. Still, it is somewhat unexpected concerning the students in humanities and social sciences at the first blush. However, due to the increasing pressure on obtaining employment opportunities upon graduation, particularly for students in humanities and social sciences, departments in humanities and social sciences in China have paid a lot of attention to provide classes that could make their students more marketable. There are similar efforts for less prestigious colleges and universities. Thus, we also see that students in the less prestigious colleges and universities have a higher level of engagement in practicum activities and take more classes related to entrepreneurship education than those in research universities. Compared to the previous studies, these findings are novel research outcomes in the entrepreneurship education research field. For example, Wu et al. (2008) [55] found entrepreneurship education still have no positive impacts for students for higher education. Tseng et al. (2015) [56] found non-STEM and STEM students' entrepreneurial intention are $70.6 \%$ and $29.4 \%$, respectively, who came from 19 cities in China. It indicated that students with business or humanities backgrounds have stronger willingness to have a start-up business [56,57].

Another surprising finding is that course taking has more significant influence than participation in practicum on student self-efficacy in entrepreneurial decision-making, and eventually on entrepreneurial intention $[31,32,34]$. The finding also reveals the importance of this entrepreneurship education research in the current context of China. This finding is somewhat different from what the literature on entrepreneurship education suggests in the previous studies, especially in the western context $[31,32,34]$. The practice-oriented entrepreneurship education has been considered as a way to deepen students' understanding of entrepreneurial knowledge, as well as effectively training students' entrepreneurial abilities and skills [42,58]. Many studies indicated that practice-oriented entrepreneurship education has had more positive effects than course-taking-oriented training in the last 3 years $[21,59]$.

One possible explanation for the differences in the roles of course-taking and practicum in student entrepreneurial development is that colleges and universities in China may be offering some practicum opportunities in an ad hoc fashion, due to the pressure to ramp up entrepreneurship education. Another possible explanation is the Chinese context where book knowledge was traditionally valued more than practical skills. The findings from this study raise the awareness among college and university leaders and faculty in China that they should pay more attention to the substance of practicum offered to students so that the practicum opportunities can have more desired influences [58].

The constant concern about a slowdown in the national economy that has been fast-growing for the past three decades would make the issue of student entrepreneurship development even more critical. Future research in the Chinese context on this topic will continue to be fruitful. Although the Ministry of Education has started to require all college students to have entrepreneurship education, differences exist in the implementation among different higher education institutions. This provides opportunities for comparative studies to examine the similarities and differences in entrepreneurial development between students in Chinese and western higher education. 
The limitations of this study are as follows, through which future research directions are presented. First, this study has a limit that dimensions of the conceptual framework are not completely ruled out because the study is limited to the observation of entrepreneur education in China. In the future, it is necessary to study new types of entrepreneur education based on emerging digital transformation techniques such as social networks sites (SNSs), Internet of things (IoT), Artificial intelligence (AI), Augmented reality (AR), human enhancement (HE), 3D printing, etc., to increase and extend the representativeness of research subjects. This study did not fully consider the motivation of participants in terms of their specific start-up field or their personality, family business background, location-based entrepreneurship culture. Therefore, future studies will be required to perform a further analysis that reflects such individual characteristics.

Author Contributions: H.M.-Investigation, Methodology, Writing-original draft, Funding acquisition, Conceptualization. C.-H.L.- Review \& editing, Visualization, Validation, Formal analysis. Y.X.: Project administration, Data curation. All authors have read and agreed to the published version of the manuscript.

Funding: Key Research Topics of the "National basic subject talent training plan" of the Ministry of Education (Grant No. 20180805); Start-up funding of Xi'an Jiaotong University [grant number 7121192301].

Acknowledgments: This paper is based on a research project supported by Key Research Topics of the "National basic subject talent training plan" of the Ministry of Education (Grant No. 20180805). The research findings reflect the authors' opinions and not necessarily those of the funding agencies. This paper is also partially supported by the start-up funding of Xi'an Jiaotong University [grant number 7121192301].

Conflicts of Interest: The authors declare no conflict of interest.

\section{Appendix A}

Table A1. Original Questionnaire on start-up Entrepreneurship practice education.

\begin{tabular}{|c|c|c|}
\hline \multicolumn{3}{|l|}{ 1. The situation of your participation in practices related to start-up during your school: } \\
\hline \multicolumn{3}{|c|}{$\begin{array}{l}\square \text { A. Never participated } \square \text { B. Rarely participated } \square \text { C. Participated occasionally } \\
\square \text { D. Sometimes participated } \square \text { E. Often participated } \\
\text { 2. The situation of your participation in learning curriculum related to start-up during your school: }\end{array}$} \\
\hline \multicolumn{3}{|l|}{$\square$ A. Never learned $\square$ B. Exposure seldom $\square$ C. Learned occasionally } \\
\hline \multicolumn{3}{|l|}{ 3. Have you participated in the following activities related to start-up? } \\
\hline \multicolumn{3}{|l|}{$\square$ (1) Participate in speeches by successful entrepreneurs in start-up or experts. } \\
\hline \multicolumn{3}{|l|}{$\square$ (2) Go to the school's start-up guidance institution for consultation. } \\
\hline \multicolumn{3}{|l|}{$\square$ (3) Visit the school-enterprise joint venture practice base. } \\
\hline \multicolumn{3}{|l|}{$\square$ (4) Participate in social surveys by enterprise. } \\
\hline \multicolumn{3}{|l|}{$\square$ (5) Participate in activities of college student start-up club. } \\
\hline \multicolumn{3}{|l|}{$\square$ (6) Participate in pre-match training for the start-up competitions. } \\
\hline \multicolumn{3}{|l|}{$\square$ (7) Participate in competitions related to start-up } \\
\hline \multicolumn{3}{|l|}{$\square$ (8) Apply for the college student start-up fund } \\
\hline 4. Have you participated in the following start-up education curriculums| & Yes & No \\
\hline $\begin{array}{l}\text { (1) The curriculums related to career development (such as career planning, employment } \\
\text { guidance, etc.) }\end{array}$ & 1 & 2 \\
\hline $\begin{array}{l}\text { (2) The curriculums related to start-up guidance (such as start-up guidance for college } \\
\text { students, etc.) }\end{array}$ & 1 & 2 \\
\hline $\begin{array}{l}\text { (3) The start-up basic curriculums (such as start-up foundation, start-up management, } \\
\text { entrepreneurship, etc.) }\end{array}$ & 1 & 2 \\
\hline $\begin{array}{l}\text { (4) The curriculums related to the identification of start-up opportunities (such as start-up } \\
\text { opportunities and project selection, identification and evaluation of start-up opportunities, } \\
\text { etc.) }\end{array}$ & 1 & 2 \\
\hline (5) The curriculums related to writing a start-up business plan & 1 & 2 \\
\hline $\begin{array}{l}\text { (6) The curriculums related to start-up fundraising (such as start-up financing, start-up } \\
\text { fundraising, etc.) }\end{array}$ & 1 & 2 \\
\hline $\begin{array}{l}\text { (7) The curriculums related to Start-up policies and regulations (such as industrial and } \\
\text { commercial regulations, tax regulations, company law and contract law, interpretation of } \\
\text { start-up policies, etc.) }\end{array}$ & 1 & 2 \\
\hline $\begin{array}{l}\text { (8) The curriculums related to start-up enterprise management (such as enterprise } \\
\text { management, start-up culture construction, etc.) }\end{array}$ & 1 & 2 \\
\hline
\end{tabular}


Table A2. Degree of Participation of College student in Entrepreneurship education.

\begin{tabular}{|c|c|c|c|c|c|c|c|c|c|c|}
\hline \multirow{2}{*}{$\begin{array}{c}\text { Degree of } \\
\text { Participation }\end{array}$} & \multicolumn{2}{|c|}{1} & \multicolumn{2}{|c|}{2} & \multicolumn{2}{|c|}{3} & \multicolumn{2}{|c|}{4} & \multicolumn{2}{|c|}{5} \\
\hline & Count & Frequency & Count & Frequency & Count & Frequency & Count & Frequency & Count & Frequency \\
\hline $\begin{array}{l}\text { Practice } \\
\text { Education }\end{array}$ & 68 & $11.4 \%$ & 424 & $70.8 \%$ & 100 & $16.7 \%$ & 7 & $1.2 \%$ & 0 & $0 \%$ \\
\hline $\begin{array}{l}\text { Curriculum } \\
\text { Education }\end{array}$ & 95 & $15.9 \%$ & 305 & $50.9 \%$ & 169 & $28.3 \%$ & 29 & $4.8 \%$ & 1 & $0.2 \%$ \\
\hline
\end{tabular}

\section{References}

1. Mok, J.K.; Lee, M.H. Globalization or Glocalization? Higher Education Reforms in Singapore. Asia Pac. J. Educ. 2003, 23, 15-42. [CrossRef]

2. Wang, Y.H.; Lee, C.H.; Trappey, A.J.C. Modularized design-oriented systematic inventive thinking approach supporting collaborative service innovations. Adv. Eng. Inform. 2017, 33, 300-313. [CrossRef]

3. Lee, C.H.; Chen, C.H.; Trappey, A.J.C. A structural service innovation approach for designing smart product service systems: Case study of smart beauty service. Adv. Eng. Inform. 2019, 40, 154-167. [CrossRef]

4. Ministry of Education of the People's Republic of China. The Education Gazette in 2000-2014 (18 April 2014). Available online: http://www.moe.gov.cn/. (accessed on 15 May 2020).

5. Lee, C.H.; Chen, C.H.; Li, F.; Shie, A.J. Customized and knowledge-centric service design model integrating case-based reasoning and TRIZ. Expert Syst. Appl. 2020, 143, 113062. [CrossRef]

6. Cruz, N.M.; Escudero, A.I.R.; Barahona, J.H. The effect of entrepreneurship education programs on satisfaction with innovation behavior and performance. J. Eur. Ind. Train. 2009, 30, 701-720.

7. Thompson, E.R. Individual entrepreneurial intent: Construct clarification and development of an internationally reliable metric. Entrep. Theory Pract. 2009, 33, 669-694. [CrossRef]

8. De Noble, A.; Jung, D.; Ehrlich, S. Initiating new ventures: The role of entrepreneurial self-efficacy. In Babson Research Conference; Babson College: Boston, MA, USA, 1999.

9. Taylor, K.; Betz, N. Applications of self-efficacy theory to understanding the treatment of career indecision. J. Vocat. Behav. 1983, 22, 63-81. [CrossRef]

10. Peng, Y.X.; Long, L.R. College student self-efficacy of entrepreneurial decision-making. Appl. Psychol. 2001, 2, 38-43.

11. Vesper, K.; Gartner, W. Measuring progress in entrepreneurship education. J. Bus. Ventur. 1997, 12, $403-421$. [CrossRef]

12. De Faoite, D.D.; Henry, C.; Johnston, K.; Sijde, P. Education and training for entrepreneurs: A consideration of initiative in Ireland and the Netherlands. Educ. Train. 2003, 45, 430-437. [CrossRef]

13. Gilje, $\varnothing$.; Erstad, O. Authenticity, agency and enterprise education studying learning in and out of school. Int. J. Educ. Res. 2017, 84, 58-67. [CrossRef]

14. Klandt, H. Entrepreneurship education and research in German-speaking Europe. Acad. Manag. Learn. Educ. 2004, 3, 293-301. [CrossRef]

15. Finkle, T.A.; Kuratko, D.F.; Goldsby, M.G. An examination of entrepreneurship centers in the United States: A national survey. J. Small Bus. Manag. 2006, 44, 184-206. [CrossRef]

16. Fayolle, A.; Gailly, B.; Lassas-Clerc, N. Assessing the impact of entrepreneurship education programmes: A new methodology. J. Eur. Ind. Train. 2006, 30, 701-720. [CrossRef]

17. Béchard, J.; Grégoire, D. Entrepreneurship education revisited: The case of higher education. Acad. Manag. Learn. Educ. 2005, 4, 2-43. [CrossRef]

18. LaForce, M.; Noble, E.; Blackwell, C. Problem-based learning (PBL) and student interest in STEM careers: The roles of motivation and ability beliefs. Educ. Sci. 2017, 7, 92. [CrossRef]

19. Lingappa, A.K.; Shah, A.; Mathew, A.O. Academic, family, and peer influence on entrepreneurial intention of engineering students. Sage Open 2020, 10. [CrossRef]

20. Rauch, A.; Hulsink, W. Putting entrepreneurship education where the intention to act lies: An investigation into the impact of entrepreneurship education on entrepreneurial behavior. Acad. Manag. Learn. Educ. 2015, 14, 187-204. [CrossRef]

21. Eichhorst, W.; Rinne, U. Promoting Youth Employment in Europe: Evidence-Based Policy Lessons. In European Youth Labour Markets; Malo, M., Moreno Mínguez, A., Eds.; Springer: Cham, Switzerland, 2018. 
22. Pardo-Garcia, C.; Barac, M. Promoting Employability in Higher Education: A Case Study on Boosting Entrepreneurship Skills. Sustainability 2020, 12, 4004. [CrossRef]

23. Laguna-Sánchez, P.; Abad, P.; de la Fuente-Cabrero, C.; Calero, R. A university training programme for acquiring entrepreneurial and transversal employability skills, a students' assessment. Sustainability 2020, 12, 796. [CrossRef]

24. Cox, L.W.; Mueller, S.L.; Moss, S.E. The impact of entrepreneurship education on entrepreneurial self-efficacy. Int. J. Entrep. Educ. 2002, 1, 229-245.

25. Nabi, G.; Walmsley, A.; Liñán, F.; Akhtar, I.; Neame, C. Does entrepreneurship education in the first year of higher education develop entrepreneurial intentions? The role of learning and inspiration. Stud. High. Educ. 2018, 43, 452-467. [CrossRef]

26. Matlay, H. The impact of entrepreneurship education entrepreneurial outcomes. J. Small Bus. Enterp. Dev. 2008, 15, 382-396. [CrossRef]

27. Egan, A.; Maguire, R.; Christophers, L.; Rooney, B. Developing creativity in higher education for 21st century learners: A protocol for a scoping review. Int. J. Educ. Res. 2017, 82, 21-27. [CrossRef]

28. Loy, J. eLearning and eMaking: 3D Printing Blurring the Digital and the Physical. Educ. Sci. 2014, 4, $108-121$. [CrossRef]

29. Vaughan, N. Student engagement and blended learning: Making the assessment connection. Educ. Sci. 2014, 4, 247-264. [CrossRef]

30. Lüthje, C.; Franke, N. The 'making' of an entrepreneur: Testing a model of entrepreneurial intent among engineering students at MIT. RD Manag. 2003, 33, 135-148. [CrossRef]

31. Tiwari, P.; Bhat, A.K.; Tikoria, J. Relationship between entrepreneurship education and entrepreneurial intentions: A validation study. In Entrepreneurship Education; Springer: Singapore, 2017; pp. 171-188.

32. Wang, S.M.; Yueh, H.P.; WEN, P. How the New Type of Entrepreneurship Education Complements the Traditional One in Developing Entrepreneurial Competencies and Intention. Front. Psychol. 2019, 10, 2048. [CrossRef]

33. Ajike, D.; Kelechi, N.G.; Hamed, A.; Onyia, V.; Kwarbai, J.D. Entrepreneurship education and entrepreneurial intentions: The role of theory of planned behaviour. Int. J. Adv. Res. Soc. Eng. Dev. Strateg. 2015, 3, $213-224$.

34. Westhead, P.; Solesvik, M.Z. Entrepreneurship education and entrepreneurial intention: Do female students benefit? Int. Small Bus. J. 2016, 34, 979-1003. [CrossRef]

35. Zaring, O.; Gifford, E.; McKelvey, M. Strategic choices in the design of entrepreneurship education: An explorative study of Swedish higher education institutions. Stud. High. Educ. 2019, 1-16. [CrossRef]

36. Krueger, N.F.; Reilly, M.D.; Carsrud, A.L. Competing models of entrepreneurial intention. J. Bus. Ventur. 2000, 15, 411-432. [CrossRef]

37. Kolvereid, L. Prediction of employment status choice intentions. Entrep. Theory Pract. 1996, $21,47-57$. [CrossRef]

38. Ajzen, I. Perceived behavioral control, self -efficacy, locus of control, and the theory of planned behavior. J. Appl. Soc. Psychol. 2002, 32, 1-20. [CrossRef]

39. Ella, H. Innovation and entrepreneurship amongst Pakeha and Maori in New Zealand. Ethn. Entrep. Struct. Process. 2004, 4, 115-140.

40. Cano, J.A.; Tabares, A. Determinants of university students' entrepreneurial intention: GUESSS Colombia study. Espacios 2017, 38, 22.

41. Faloye, D.O.; Olatunji, O.D. Entrepreneurship education and self-employment intentions among fresh graduates in Nigeria. J. Econ. Sustain. Dev. 2018, 12, 146-154.

42. Akinbode, M.; Moses, C.; Olokundun, A.M.; Adeniji, C.G. Assessing the Influence of Entrepreneurship Education on Self efficacy, Attitude and Entrepreneurial Intentions. Covenant J. Entrep. 2018, 1, 47-59.

43. Bagheri, A.; Lope Pihie, Z.A.; Krauss, S.E. Entrepreneurial leadership competencies among Malaysian university student entrepreneurial leaders. Asia Pac. J. Educ. 2013, 33, 493-508. [CrossRef]

44. Chen, C.C.; Greene, P.G.; Crick, A. Does entrepreneurial self-efficacy distinguish entrepreneurs from managers? J. Bus. Ventur. 1998, 13, 295-316. [CrossRef]

45. Lent, R.W.; Brown, S.D. Social cognitive approach to career development: An overview. Career Dev. Q. 2005, 44, 310-321. [CrossRef]

46. Wang, C.; Kim, D.H.; Bai, R.; Hu, J. Psychometric properties of a self-efficacy scale for English language learners in China. System 2014, 44, 24-33. [CrossRef] 
47. Bandura, A. Social foundations of thought and action: A social cognitive theory. J. Appl. Psychol. 1986, $12,169$.

48. Staggs, G.D.; Larson, L.M.; Borgen, F.H. Convergence of specific factors in vocational interests and personality. J. Career Assess. 2003, 11, 243-261. [CrossRef]

49. Naktiyok, A.; Karabey, C.N.; Gulluce, A.C. Entrepreneurial self-efficacy and entrepreneurial intention: The Turkish case. Int. Entrep. Manag. J. 2010, 6, 419-435. [CrossRef]

50. Guerrero, M.; Urbano, D.; Fayolle, A.; Klofsten, M.; Mian, S. Entrepreneurial universities: Emerging models in the new social and economic landscape. Small Bus. Econ 2016, 3, 551-563. [CrossRef]

51. Kazumi, T.; Kawai, N. Institutional support and women's entrepreneurial self-efficacy. Asia Pac. J. Innov. Entrep 2017, 11, 345-365. [CrossRef]

52. Liu, W.; Xu, K. Are entrepreneurial opportunity and entrepreneurial intentions correlated? Nankai Manag. Rev. 2011, 5, 83-90.

53. Oyugi, J.L. The Mediating Effect of Self-Efficacy on the Relationship Between Entrepreneurship Education and Entrepreneurial Intentions of University Students. J. Entrep. Manag. Innov. 2015, 11, 31-56. [CrossRef]

54. Izquierdo, E.; Buyens, D. Impact assessment of an entrepreneurship course on students' entrepreneurial competencies: A constructivist perspective. Int. Adv. Econ. Res. 2008, 14, 395-406.

55. Wu, S.; Wu, L. The impact of higher education on entrepreneurial intention of university students in China. J. Small Bus. Enterp. Dev. 2008, 15, 752-775. [CrossRef]

56. Fanqi, Z.; Muqiang, Z.; Qian, L. An Empirical Study on the Influencing Factors of Entrepreneurship Intention-Based on a Questionnaire Survey of College Students' Social Entrepreneurship. J. Shantou Univ. Humanit. Soc. Sci. Ed. 2015, 31, 70-76. (In Chinese)

57. Chen, X.Q. Research on the Influencing Factors of Undergraduates' Entrepreneurship Intentions-Based on the Investigation and Analysis of Four Universities in Shiyan City. J. Hubei Adult Educ. Inst. 2019, 5, 8. (In Chinese)

58. David, R. Practical theories from entrepreneurs' stories: Discursive approaches to entrepreneurial learning. J. Small Bus. Enterp. Dev. 2004, 11, 195-202.

59. Li, L. A discussion on the influence mechanism of innovative education level on the prospects of undergraduates' entrepreneurship. J. Anyang Norm. Univ. 2019, 4, 26. (In Chinese)

(C) 2020 by the authors. Licensee MDPI, Basel, Switzerland. This article is an open access article distributed under the terms and conditions of the Creative Commons Attribution (CC BY) license (http://creativecommons.org/licenses/by/4.0/). 